\title{
Motility as a Factor in Bowel Colonization by Roseburia cecicola, an Obligately Anaerobic Bacterium from the Mouse Caecum
}

\author{
By THADDEUS B. STANTON† AND DWAYNE C. SAVAGE* \\ Department of Microbiology, University of Illinois, 407 South Goodwin Avenue, Urbana, \\ IL 61801, USA.
}

(Received 4 May 1983; revised 8 August 1983)

\begin{abstract}
Roseburia cecicola strain GM is a motile obligate anaerobe that was isolated from mouse caecal mucosa. Twenty-five strains of motility mutants were obtained from populations of strain GM (wild-type) that had been exposed to UV light. Unlike GM cells, mutant bacteria were either non-motile and non-flagellated (Fla ${ }^{-}$) or migrated slowly or atypically in semi-solid medium. Strain GM and two mutant strains, SLS (Fla ${ }^{-}$) and WES (atypically motile), were used in mouse colonization experiments. In separate experiments, each strain colonized $\left(4.8 \times 10^{9}\right.$ to $1.5 \times$ $10^{10} \mathrm{c}$.f.u. per $\mathrm{g}$ caecum) the caecum of germfree mice inoculated intragastrically with pure cultures of the bacteria. In mice mono-associated with either mutant strain, bacteria which were non-motile or atypically motile predominated in their caeca ( $>99 \%$ of total bacteria recovered). In mice mono-associated with motile cells of strain GM, mutant strains which had lost wild-type motility became predominant in the caecal populations $(97 \%$ of total bacteria recovered at 48 to 70 days after inoculation). Mice mono-associated with either strain SLS or strain GM were colonized by one strain each of Escherichia coli, Candida pintolopesii, a Bacteroides sp., and a Clostridium sp. Most ( $99 \%$ ) of the $R$. cecicola cells recovered from the caeca of these animals had typical wild-type motility. Motility, although not essential for $R$. cecicola to colonize germfree mice, is apparently advantageous to this bacterium when other micro-organisms are present with it in the mouse caecum. Motility may thus be essential for $R$. cecicola to colonize conventional laboratory mice.
\end{abstract}

\section{INTRODUCTION}

Motility is a commonly reported characteristic of micro-organisms colonizing tissues and organs of mammals (Rosebury, 1962: Gordon \& Dubos, 1970; Allweiss et al., 1977; Stanton \& Savage, 1983a). These motile colonizers include pathogenic as well as non-pathogenic bacteria. There is only limited understanding, however, of the role of motility and chemotaxis in the interactions of bacteria with host tissues and with other micro-organisms in their habitats (Chet \& Mitchell, 1976).

Recently, motility has been associated with the virulence of certain bacterial pathogens. In comparison with motile wild-type strains, non-motile mutant strains of Vibrio cholerae had decreased virulence in infant mice (Guentzel \& Berry, 1975) and ligated loops of rabbit intestine (Yancey et al., 1978). Similarly, a strain of Pseudomonas aeruginosa was less virulent in a population of mice immunized with flagellar preparations isolated from the pathogen than in non-immunized animals (Holder et al., 1982). Thus, when the motility of these pathogens was impaired genetically or immunologically, their virulence was reduced. Bacteria that become non-motile or non-chemotactic may have a reduced ability to locate near, adhere to, or penetrate into host tissues, early steps in many disease processes (Savage, 1980; Freter et al., 1978). Relative to wild-type bacteria, non-motile or non-chemotactic $V$. cholerae strains have an

+Present address: National Animal Disease C'enter. USDA. PO Box 70. Ames, IA 50010. USA 
impaired capacity to penetrate the mucus gel overlying the intestinal epithelium and to adsorb to underlying intestinal tissues (Guentzel et al., 1977; Freter et al., 1979, 1981). Likewise, in comparison with motile wild-type strains, fewer cells of non-motile mutant strains of Salmonella typhimurium can contact and attach to HeLa cells (Jones et al., 1981). Motility and chemotaxis are likely to be important for host colonization by a number of pathogens.

Many non-pathogenic bacteria indigenous to mammalian hosts are motile. To begin an investigation of the role of motility in colonization of the mouse intestinal canal by indigenous bacteria, we recently isolated motile bacteria from caecal scrapings. Over two-thirds of the bacteria in the scrapings were motile (Stanton \& Savage, 1983a). One of the isolates was Roseburia cecicola strain GM (gen. nov., sp. nov.), an obligately anaerobic bacterium with 20-35 flagella per cell (Stanton \& Savage, 1983b). Motility appears to be a metabolically expensive trait for this bacterium (Stanton \& Savage, 1983a). For this reason we hypothesized that motility is a favourable, and perhaps essential, adaptation for $R$. cecicola cells colonizing the mouse caecum (Stanton \& Savage, 1983a). In this paper we report the isolation and preliminary characterization of $R$. cecicola mutant strains defective in motility. We used two of these strains in experiments to attempt to assess whether motility is essential for the bacterium to colonize mice. Our findings suggest that motility is important when $R$. cecicola colonizes the mouse caecum with micro-organisms of other genera.

\section{METHODS}

Micro-organisms and culture conditions. Rosehuria cecicola strain GM was isolated from the mouse caecal mucosa (Stanton \& Savage, 1983a,b). All strains of the organism described in this paper were cultured routinely under anaerobic conditions in VTY broth and VTY solid medium (VTY broth with Difco Noble agar $0 \cdot 7^{\circ}, \mathrm{w} / \mathrm{v}$ ) (Stanton \& Savage, 1983 b). VTY medium contained: yeast extract, $5.0 \mathrm{~g}$; trypticase peptone, $10 \cdot 0 \mathrm{~g}$; haemin $\left(0 \cdot 05^{\circ}, \mathrm{w} / \mathrm{v}\right.$, in $\left.0.01 \mathrm{M}-\mathrm{NaOH}\right), 10 \cdot 0 \mathrm{ml}: \mathrm{L}$-cysteine. $\mathrm{HCl}$ monohydrate, $1.0 \mathrm{~g} ;$ resazurin $\left(0 \cdot 1{ }^{\circ}{ }_{0}, \mathrm{w} / \mathrm{v}\right), 1 \cdot 0 \mathrm{ml} ; \mathrm{salts}$ solution A, $200 \mathrm{ml}$; salts solution $\mathrm{B}, 200 \mathrm{ml}$; distilled water, $560 \mathrm{ml}$; stock VFA solution, $3.0 \mathrm{ml} ; \mathrm{NaHCO}_{3}(5 \%$, $\mathrm{w} / \mathrm{v}), 10.0 \mathrm{ml} ;$ glucose $(10 \%, \mathrm{w} / \mathrm{v}), 20.0 \mathrm{ml}$. Salts solution A contained (g per litre of distilled water): $\mathrm{CaCl}_{2} .2 \mathrm{H}_{2} \mathrm{O}$, $0.6 \mathrm{~g} ; \mathrm{MgSO}_{4}, 0.45 \mathrm{~g}$. Salts solution B contained (g per litre of $0.05 \mathrm{~m}$-potassium phosphate buffer, $\mathrm{pH} \mathrm{7.4):} \mathrm{NaCl}$, $4.5 \mathrm{~g} ;\left(\mathrm{NH}_{4}\right)_{2} \mathrm{SO}_{4}, 4.5 \mathrm{~g}$. Stock VFA solution (total volume, $31 \mathrm{ml}$ ) contained the following acids: acetic, $17 \mathrm{ml}$; propionic, $6 \mathrm{ml}$; n-butyric, $4 \mathrm{ml}$; n-valeric, $1 \mathrm{ml}$; isovaleric, $1 \mathrm{ml}$; isobutyric, $1 \mathrm{ml}$; DL- $\alpha$-methylbutyric, $1 \mathrm{ml}$. The anaerobic atmosphere over VTY medium was a deoxygenated mixture of $95 \% \mathrm{~N}_{2} / 5 \% \mathrm{CO}_{2}$. VTYss (semi-solid) medium was VTY medium with $0.3 \%$ Noble agar and $0.05 \%$ glucose and was used to isolate $R$. cecicola motility mutants and to recover the organism from mono-associated mice. The mutant strains have been described on the basis of their colonial morphology in VTYss medium 24 to $28 \mathrm{~h}$ after the medium was inoculated (100 to 500 colonies per plate). M medium was VTY medium, Noble agar, glucose, yeast extract, and trypticase peptone at final concentrations $\left(\mathrm{g}^{-1}\right)$ of $3 \cdot 0,0 \cdot 5,2 \cdot 0$ and $4 \cdot 0$ respectively and was used to investigate the ability of mutant strains to migrate in a semisolid environment. SD medium was VTY medium with (per litre): Noble agar, 3.0 g; soluble starch, $10.0 \mathrm{~g}$; nalidixic acid, $50 \mathrm{mg}$; and tetracycline. $\mathrm{HCl}, 20 \mathrm{mg}$. The antibiotics were purchased from Sigma. SD medium was used for the selective isolation and identification of $R$. cecicola from mouse caeca colonized by additional micro-organisms. Starch hydrolysis as determined by iodine staining (Skerman, 1969) was used to differentiate $R$. cecicola colonies from those of other bacteria. TS broth, for diluting bacterial cultures, was an anaerobic solution of salts, L-cysteine. $\mathrm{HCl}$, and trypticase peptone (Stanton \& Savage, 1983a).

Escherichia coli 314D and Bacteroides 116-2 were cultured anacrobically in VTY medium. The yeast Candida (Torulopsis) pintolopesii 108-1 was cultured aerobically in Difco Sabouraud-dextrose broth. Clostridium 109-2 was cultured anaerobically in pre-reduced Difco BHI broth. Cultures were incubated at 37 ' $\mathrm{C}$. In broth culture, Candida, Bacteroides and (\%ostridium cells were non-motile: $E$. coli cells were motile. All of these micro-organisms were isolated from the gastrointestinal tract of conventional laboratory mice and have been kept as stock cultures in our laboratory (Tannock \& Savage. 1976: Artwohl \& Savage. 1979). Escherichia coli 314D was isolated at the same time as $R$. cecicola (Stanton \& Savage, 1983a) and was identified on the basis of physiological characteristics (Fnterotube II, Roche Diagnostics, Nutley. NJ, USA). For every experiment, cultures were obtained from an isolated colony of each micro-organism.

Isolation of mutant strains. Mutagenesis with UV light was used to obtain strains of $R$. cecicola with motility characteristics different from those of wild-type cells. Broth cultures $\left(5 \mathrm{ml}: 2 \times 10^{\times}\right.$cells $\left.\mathrm{ml} \quad{ }^{1}\right)$ of cells of strain $\mathrm{GM}$ in the exponential phase of growth were deposited in the bottom half of plastic Petri plates in an anaerobic chamber (Coy Manufacturing ( ${ }^{\circ}$.. Ann Arbor. Mich., USA). The chamber was filled with a mixture of $95^{\circ}$. $\mathrm{N}_{2} / 5^{\circ}{ }_{0} \mathrm{CO}_{2} / 3^{\circ}{ }_{0} \mathrm{H}_{2}$. The Petri plates had been kept in the chamber for at least $48 \mathrm{~h}$ to allow oxygen to diffuse from their plastic surfaces. Bacteria in the broth cultures were exposed to short-wavelength UV radiation: the 
uncovered Petri plates were rotated at 75 r.p.m. for 7 to $8 \mathrm{~min} 15 \mathrm{~cm}$ beneath a UV light source (Mineralight Lamp, model UV SL-25, UV Products Inc., San Gabriel, Calif., USA). This exposure reduced the populations of viable bacteria by 95 to $99 \%$. After the exposure, culture samples were immediately diluted (1/100) into VTY broth $(2 \mathrm{ml})$ in sterile, foil-wrapped, culture tubes.

The inoculated culture tubes were placed in a $37^{\circ} \mathrm{C}$ incubator to allow gene segregation in the dividing bacteria. After $4 \mathrm{~h}$ (two population doublings), the cultures were serially diluted in TS broth. Samples $(0 \cdot 1 \mathrm{ml})$ of the dilutions were placed into sterile Petri plates and mixed with either of two melted agar media $\left(40{ }^{\circ} \mathrm{C}, 15 \mathrm{ml}\right.$ per plate). VTY solid medium containing rifampicin $\left(5.0 \mu \mathrm{g}^{-1}\right.$ final concentration) was used to estimate the number of Rif bacteria in the culture. VTYss medium ( $0.3_{0}^{\circ}$ Noble Agar, final concentration) was used to enumerate and isolate bacteria with altered motility characteristics. After the agar media had solidified. Petri plates were incubated at $37^{\circ} \mathrm{C}$ for 24 to $48 \mathrm{~h}$. Plates containing VTYss medium were incubated agar side down. Bacterial colonies appearing in VTYss medium were examined in order to select mutant strains with altered motility. Wildtype bacteria formed diffuse colonies, 2 to $5 \mathrm{~mm}$ in diameter. Putative motility mutants formed pin-point colonies $(\leqslant 0.5 \mathrm{~mm})$ which were cloned by passage three times in VTYss medium. In this manner, 25 strains were obtained from cultures in separate experiments or from a different dilution of a mutagenized culture in the same experiment (see above). Thus, each strain originated from a different parental cell. All cells of the mutant strains resembled parental cells in gross morphology. Moreover, cells of the mutant strains could not be cultured aerobically and had the same sensitivity as wild-type cells to the antibiotics vancomycin. erythromycin, nalidixic acid. and tetracycline (Stanton \& Savage. 1983h).

Motility studies. In experiments to determine the ability of $R$. cecicola strains to move in liquid medium, samples of VTY broth cultures of the organism in the exponential growth phase were drawn into flat glass capillaries (Vitro Dynamics, Rockaway, NJ, USA). The motility of bacteria in the broth at $37^{\circ} \mathrm{C}$ was assessed by microscope observations of suspended cells near the capillary centre. For these observations the microscope was placed in an incubator $(37 \mathrm{C})$. The ocular lenses extended through an opening in the incubator door for comfortable viewing. Wild-type cells of $R$. cecicola (strain GM) in VTY broth were always rapidly motile in the centre of the flat capillary. Bacteria were non-motile. however, near the open ends of the capillary where the medium was undoubtedly oxidized. The ability of $R$. cecicola strains to migrate through a semi-solid medium was also determined. Samples $(5 \mu l)$ of broth cultures were spotted in the centre of $\mathbf{M}$ medium in Petri plates, after which the plates were inverted and incubated at $37 \mathrm{C}$. After 30 to $36 \mathrm{~h}$, the capacity of the bacteria to migrate through the semi-solid medium was assessed by examining the expansion of visible growth away from the inoculum site.

Microscop!. Cells of $R$. cecicola in wet mount preparations were observed with a Zeiss GFL microscope equipped for phase-contrast microscopy. Photomicrographs were taken of bacterial cells as described by Stanton \& Savage $(1983 \mathrm{~h})$. The bacteria were also negatively stained with phosphotungstic acid $(1 \%, \mathrm{w} / \mathrm{v}, \mathrm{pH} 6.5)$ and examined by electron microscopy (Stanton \& Savage, 1983h).

Association of gnotohiotic mice'. In order to evaluate whether or not motility is essential to $R$. cecicola in its colonization of mice, we associated germfree mice with strains of the organism differing in motility. The germfree mice were descended from ( RI: (D-1 (ICR) GN mice purchased from Charles River Breeding Laboratories (Wilmington, Mass. USA) and bred in our facility. Animals of both sexes were 10 to 12 weeks old at the beginning of each experiment. (are of the mice and monitoring of their germfree status has been described (Stanton \& Savage, $1983 a$ ).

(iermfree mice were inoculated intragastrically with samples of exponential-phase cultures of $R$. cecicola strains (jM. SLS. or WF.S (0.5 ml or approx. $10^{\circ}$ cells per mouse). The population densities and motility of colonizing bacteria were determined from cultures of caecal homogenates made at various times after the animals had been inoculated (Stanton \& Savage, 1983 h). Each mouse was killed by cervical dislocation. The abdominal viscera were exposed and the caccum was excised with a transverse cut across the large lobe beginning approximately 1 to $2 \mathrm{~mm}$ below the ileo-ciacial and colono-caecal junctions. The excised caccum was placed in a pre-weighed tissue homogenizer tube containing $9 \mathrm{ml}$ of cold 15 (') pre-reduced VTY broth. Tubes containing caeca were weighed. Then the organs were homogenized in the VTY broth with Teflon pestles driven by a Tri-R Stir-R (Tri-R Instruments, Rockville Center, NY, USA) operating at a setting of 3 . The tubes were flushed with a gas mixture of $95^{\circ} \mathrm{N}_{2} / 5^{\circ} \mathrm{CO}_{2}$ and homogenates were kept cold $\left(5^{\circ} \mathrm{C}\right)$. Tubes were sealed with Neoprene stoppers.

Caecal homogenates obtained as described above were placed in a Coy anaerobic chamber and serially diluted in TS broth (Stanton \& Savage, $1983 \mathrm{~b})$. Samples $(0.1 \mathrm{ml})$ of the dilutions were mixed with melted $\left(40{ }^{\circ} \mathrm{C}\right)$ VTY agar medium $(15 \mathrm{ml})$ in disposable plastic Petri plates. After the medium had solidified. the inoculated plates were incubated at $37 \mathrm{C}$ in the anaerobic chamber. After 30 to $36 \mathrm{~h}$. the plates were examined. Small $(\leqslant 0.5 \mathrm{~mm})$. discrete colonies of $R$. cecicola in the media were considered to contain bacteria with altered motility. Large (1 to $3 \mathrm{~mm}$ ). diffuse colonies were considered to contain bacteria with wild-type motility. In separate but simultaneous experiments. broth cultures of $R$. cecicola wild-type and motility mutant strains were diluted and inoculated into VTYss or SD media. The colonial morphologies of these strains were compared with those of bacteria recovered from the mouse calecum. thus facilitating an evaluation of the motility of bacteria colonizing the animals. 
Estimates of the population densities of $R$. cecicola either cultured in broth or colonizing caeca were two- to threefold lower when the antibiotic-containing SD medium was used for viable cell counts than when VTYss medium was used in the same experiment. We did not find that SD medium selected for a particular motility type of $R$. cecicola. Adjustments have not been made for decreased population estimates resulting from the use of SD medium

In some experiments, mice were 'penta-associated'. Germfree mice were first inoculated by intragastric gavage with cultures of $R$. cecicola strain GM or SLS, and $10 \mathrm{~d}$ later the mono-associated animals were inoculated orally with $0.1 \mathrm{ml}$ BHI broth containing E. coli $314 \mathrm{D}$ (10 $0^{7}$ cells), Bacteroides $116-2\left(2 \times 10^{7}\right.$ cells $)$, and Candida pintolopesii $108 \cdot 1\left(2 \times 10^{\mathrm{h}}\right.$ cells $)$. Four days after this second inoculation, the animals were further inoculated intragastrically with $0.5 \mathrm{ml}$ of a BHI broth culture of Clostridium 109-2 (10 cells). Population densities of the micro-organisms were estimated by direct cell counts. Penta-associated mice were killed between 30 and $70 \mathrm{~d}$ after they had been inoculated with $R$. cecicola. All five micro-organisms colonized the mice, as determined by direct microscopic observations of gastrointestinal contents or culture of bacteria in the contents.

In other experiments, we sought to determine the influence of a complex variety of micro-organisms on the population levels and motility of $R$. cecicola colonizing the mouse caecum. Thus, mice previously colonized for 8 weeks by $R$. cecicola GM were given an SPF (specific pathogen free) microflora by caging the mono-associated animals with SPF mice in germfree isolators (Whitt \& Savage, 1980). The fur of the mono-associated mice had been trimmed so they could be identified. The SPF mice were descended from Charles-River SPF mice and had been maintained in our laboratory as though they were germfree. [Charles-River SPF mice are prepared by the supplier by associating germfree mice with stock cultures of eight micro-organisms isolated from conventional laboratory mice.] We were not able to isolate bacteria resembling $R$. cecicola, i.e. able to hydolyse starch and similar in morphology, from these SPF mice. Six weeks after they were caged with the SPF animals, the previously mono-associated mice were killed and attempts were made to recover $R$. cecicola from their caeca by methods described above.

\section{RESULTS}

\section{Mutant isolation}

Twenty-five strains with colonial morphologies different from that of wild-type strain GM were isolated from the survivors of UV mutagenesis of $R$. cecicola. Unlike strain GM, these strains formed small, non-spreading colonies in VTYss medium. Four of these strains reverted at high frequency (approx. $10^{-3}$ to $10^{-2}$ ) to wild-type colonial form. Two other strains became contaminated. These six strains were discarded. The remaining strains had stable colonial morphologies in VTYss medium (estimated reversion frequency $<10^{-5}$ ). Cells of each strain differed from wild-type cells in motility, as discussed below.

The frequency at which motility mutants arose spontaneously in wild-type populations could not be determined; growth of wild-type cells in VTYss medium obscured the small colonies of motility mutants. Thus, a direct and quantitative evaluation of the UV mutagenesis procedure for increasing the incidence of motility mutants could not be made. Consequently, the frequency of motility mutants was related to the frequency of rifampicin-resistant strains in mutagenized populations. Motility mutants and Rif ${ }^{r}$ bacteria $(5.0 \mu \mathrm{g}$ rifampicin per litre of medium) were obtained simultaneously from bacterial cultures exposed to UV light. In mutagenized cell populations $\mathrm{Rif}^{\mathrm{r}}$ bacteria occurred at a frequency of approximately $10^{-5}$. Strains with altered motility were found at a frequency of $10^{-4}$. In non-mutagenized populations, $R$ if ${ }^{r}$ bacteria arose spontaneously at a frequency of $10^{-7}$.

\section{Categories of motility mutants}

On the basis of their colonial morphology, motility in broth, migration or growth in semi-solid agar medium, and cell morphology, the 19 strains of $R$. cecicola motility mutants could be placed in three general categories. Cells of wild-type strain GM were actively motile in broth $(\geqslant 99 \%$ of cslls) and rapidly migrated through a semi-solid medium, forming numerous (six or seven) concentric growth rings (Fig. $1 a$ ). Migration and growth of this sort is a characteristic of motile bacteria responding to chemo-attractants or chemo-repellents in the medium (Adler, 1966). GM cells formed diffuse colonies, 2 to $5 \mathrm{~mm}$ in diameter, which became expanding rings of growth after approximately $48 \mathrm{~h}$ incubation. Flagella were readily visible on wild-type cells (Fig. $2 a$ ). The phenotype of $\mathrm{GM}$ is $\mathrm{Mot}^{+} \mathrm{Fla}^{+}$. One category of motility mutants contained six strains that 
were non-motile in broth, unable to migrate in semi-solid medium (Fig. 1c), and devoid of flagella (Fig. $2 b$ ). These strains formed pinpoint colonies, 0.2 to $0.5 \mathrm{~mm}$ in diameter. Strain SLS belongs to this category. The phenotypic designation of these mutants is $\mathrm{Fla}^{-}$. The second category contained eleven strains that were flagellated (Fig. $2 c$ ) but non-motile or sluggishly motile in broth medium. Cells of these strains migrated atypically in a semi-solid agar medium. That is, their migration through the medium was slow and growth rings did not form (Fig. $1 b$ ). Failure to form concentric growth rings may indicate that these bacteria are defective in chemotaxis. Colonies were 0.5 to $1.0 \mathrm{~mm}$ in diameter and either diffuse with fuzzy edges or granular in appearance. Strain WES belongs to this category. The phenotypic designation of these mutants is $\mathrm{Fla}^{+}$, atypically motile. A third category contained two strains. These strains were flagellated, actively motile in broth, and formed growth rings similar to those in strain GM. Growth rings of these mutant strains expanded at a slower rate, however, than those of the wildtype. A possible explanation for the slower migration is that mutant cells had fewer flagella than strain GM, a situation that has been reported for a slowly migrating Salmonella typhimurium (Enomoto, 1965). Strains of this third category have not been examined by electron microscopy.

The 19 mutant strains were obligate anaerobes with the cellular morphology and the antibiotic sensitivities of wild-type bacteria. Revertant strains with wild-type motility could be obtained from many of the mutant strains cultured on $M$ medium. These revertants formed growth 'blebs' protruding from colonial growth of the mutants after 48 to $96 \mathrm{~h}$ of incubation (Fig. $1 d$ ). On the basis of these observations, we believe that all isolates were strains of $R$. cecicola and descendants of parental strain GM. At this time, however, we cannot rule out the possibility that the motility mutant strains may have sustained changes in genes encoding functions not detected by the methods used. As shall be seen, such mutations, if they existed, did not obviously influence the capacity of the strains to colonize the guts of germ-free mice.

\section{Colonization of gnotobiotic mice}

Cultures of motility mutants SLS $\left(\mathrm{Fla}^{-}\right)$and WES (Fla ${ }^{+}$, atypically motile) were maintained through seven transfers $(1 \%, v / v$, inocula) in VTY broth. At transfers 3 and 7 , dilutions of the broth cultures were inoculated into VTYss medium in Petri plates. Isolated colonies of either strain had the same morphology as when they were first isolated, and were easily distinguishable from colonies of wild-type strain GM. On the basis of this observation we concluded that SLS and WES were genetically stable for their particular type of motility in citro. In terms of population doubling times and final cell densities in VTY broth batch cultures, mutant strains SLS and WES were not distinguishable from wild-type strain GM. Therefore, we used these strains for mouse colonization experiments.

Strains SLS, WES and GM colonized the caeca of germfree mice inoculated with these bacteria (Table 1). Caecal population densities for the motility mutant strains were similar to those of wild-type strain GM $\left(5 \times 10^{4}\right.$ to $10^{10} \mathrm{c}$.f.u. per g caecal homogenate $)$. Thus wild-type motility was not essential for $R$. cecicola to colonize germfree mice. Unexpectedly, many ( 2 to $99 \%$ ) of the bacteria recovered from mice mono-associated with strain GM formed colonies typical of motility mutant strains (Table 1 , mice A to D). In mouse A, these bacteria represented at least $99 \%$ of the colonizing population.

To establish that these colonial variants were motility mutants of $R$. cecicola, we isolated, from four mono-associated mice, 15 strains producing small colonies. The isolates were tested for antibiotic sensitivity and evaluated for motility as described for colonial variants resulting from UV mutagenesis. All isolates had the antibiotic sensitivities of $R$. cecicola. Nine strains migrated atypically in semi-solid medium; five strains were non-flagellated: one strain migrated at a slower rate than the wild-type in semi-solid medium. Most (14/15) of these spontaneous motility mutants produced revertant strains with wild-type motility in $\mathbf{M}$ medium (as in Fig $1 d$ ). These results indicate that colonial variants recovered from mice colonized by wild-type bacteria were motility mutants of $R$. cecicola.

Surprisingly, revertants with wild-type motility were recovered from mice inoculated with motility mutants (Table 1, mice F, J, L, M). With the exception of the bacteria recovered from 

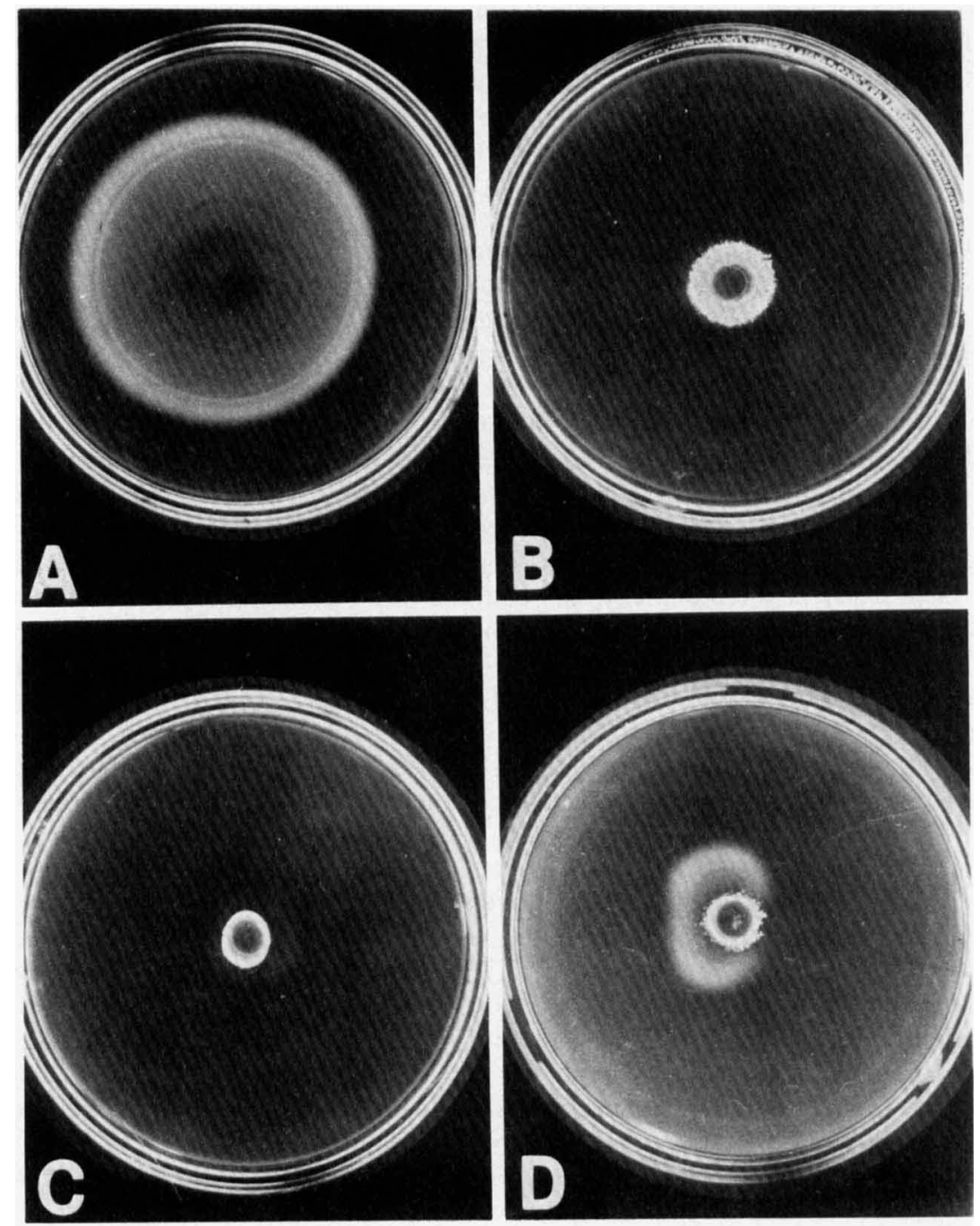

Fig. 1. Migration of $R$. cecicola strains in $\mathrm{M}$ agar medium (Noble agar, $0 \cdot 3 \%$, w/v, final concentration). Samples $(5 \mu \mathrm{l})$ of broth cultures of the bacteria were inoculated in the centre of the agar medium. Petri plates containing inoculated medium were incubated at $37^{\circ} \mathrm{C}$ for 36 to $48 \mathrm{~h}$. A, Strain GM (wild type). Bacterial growth appears diffuse and there are concentric growth rings. B, Strain WES (Fla ${ }^{+}$, atypically motile). Bacteria are motile but have migrated only a short distance from the inoculation site without forming growth rings. C, Strain SLS $\left(\mathrm{Fla}^{-}\right)$. D, Strain $\mathrm{RMS} \mathrm{(Fla}{ }^{+}$, atypically motile). Revertant strains with wild-type motility appear as diffuse growth expanding away from the denser growth of RMS mutant cells.

mouse $\mathrm{M}$, these motile revertants were a small proportion $(<0.1 \%)$ of the total colonizing population. Cells of every revertant colony examined were flagellated and resembled $R$. cecicola GM in morphology.

\section{Motility of $R$. cecicola in mono-associated and penta-associated mice}

The above finding indicated that motility is not essential for $R$. cecicola to colonize germfree mice and is an unstable characteristic of wild-type bacteria colonizing mono-associated mice. Therefore, we sought to determine whether other micro-organisms affected the motility types of $R$. cecicola populations colonizing the mouse caecum. Germfree mice were associated with 

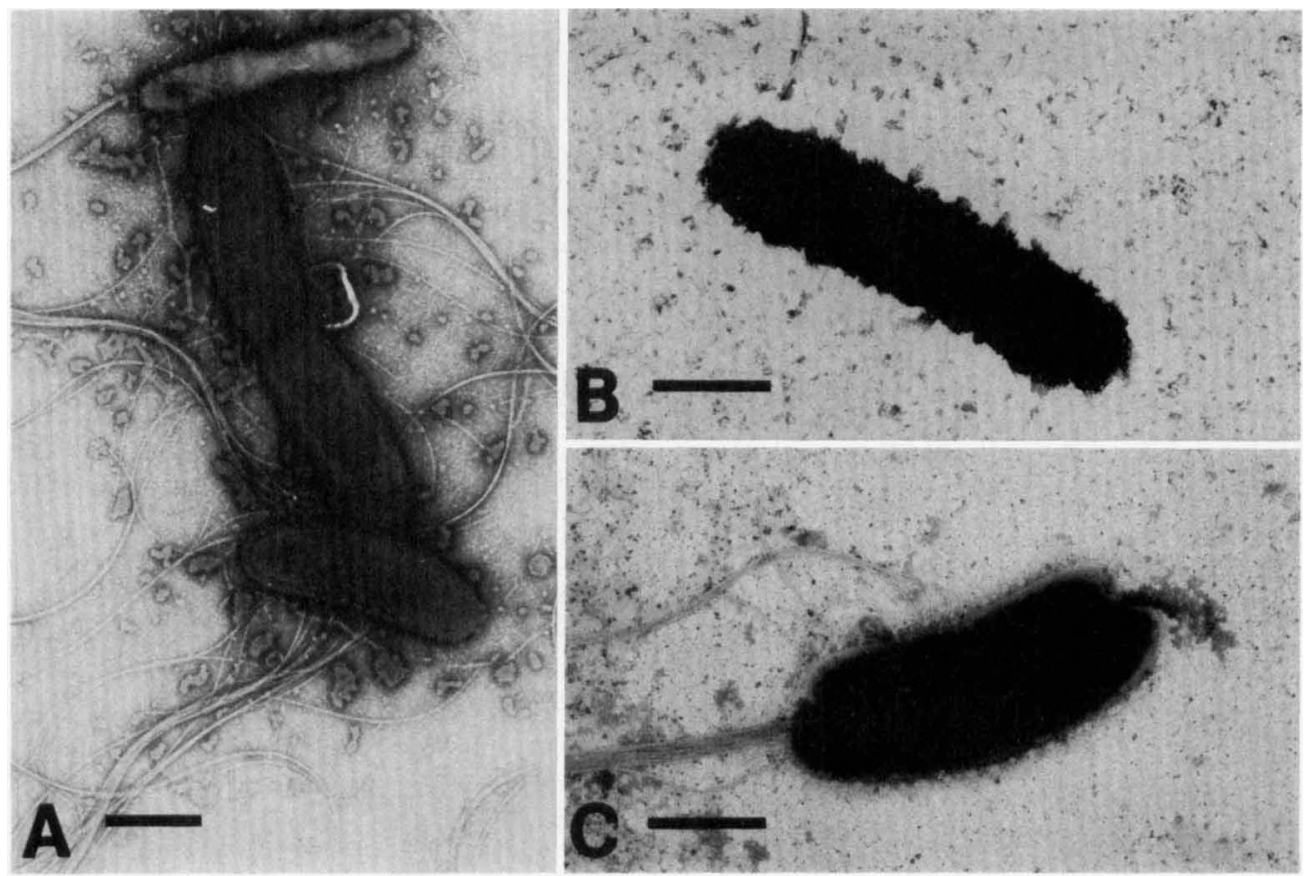

Fig. 2. Electron micrographs of negatively stained (phosphotungstic acid, $1 \%$ w/v, pH 6.5 ) cells of $R$. cecicola strains. A, Strain GM (wild type): B, strain SLS (Fla ${ }^{-}$); C, strain WES (Fla ${ }^{+}$, atypically motile). The marker bars represent $0.7 \mu \mathrm{m}$.

Table 1. Colonization of the caecum of germfree mice by R. cecicola strains GM, SLS and WES

Each mouse initially received $10^{8}$ to $2 \times 10^{8}$ cells of the particular strain by intragastric gavage. Bacteria were recovered from animals killed three weeks after inoculation of GM or SLS and five weeks after inoculation of WES.

\section{Bacterial} strain inoculated

GM

SLS

WES

\section{Phenotypic designation}

$\mathrm{Mot}^{+} \mathrm{Fla}^{+}$

Fla $^{-}$

$\mathrm{Fla}^{+}$, atypically motilet
No. of caecal bacteria

Mouse $\left[10^{-4} \times\right.$ c.f.u. $\left.(g \text { wet wt })^{-1}\right]$

10
$8 \cdot 8$
$4 \cdot 8$
$4 \cdot 9$
13
$8 \cdot 2$
11
$9 \cdot 0$
$7 \cdot 7$
10
10
$8 \cdot 7$
15

Proportion of colonies non-motile or atypically motile* $(\%)$

$$
\begin{array}{r}
99 \\
2 \\
33 \\
26 \\
>99 \\
>99 \\
>99 \\
>99 \\
>99 \\
>99 \\
>99 \\
>99 \\
34
\end{array}
$$

* Motile colonies in VTYss medium were diffuse, spreading ( 1 to $3 \mathrm{~mm}$ in diameter). Non-motile or atypically motile colonies were discrete, pin-point $(0.2$ to $0.5 \mathrm{~mm}$ in diameter). Bacteria with wild-type motility comprised a low proportion $(<0 \cdot 1 \%$ ) of the total bacteria recovered from mice F, J, and L. Bacteria with wild-type motility were not recovered $(<0.01 \%$ of total population) from mice $\mathrm{E}, \mathrm{G}, \mathrm{H}, \mathrm{I}$ and $\mathrm{K}$.

+ Strain WES cells migrated in semisolid medium but did not form concentric growth rings. 
Table 2. Motility of $R$. cecicola cells recovered from the caecum of mono-associated and pentaassociated mice colonized either with strain $G M$ or with strain $S L S\left(\mathrm{Fla}^{-}\right)$

Each mouse initially received $10^{8}$ to $2 \times 10^{8}$ cells of GM or SLS by intragastric gavage. Ten to fourteen days later, mice to become penta-associated were inoculated with cultures of $E$. coli, Bacteroides $\mathrm{sp}$., Candida pintolopesii, and Clostridium $\mathrm{sp}$. Cells of $R$. cecicola were recovered by inoculating dilutions of caecal homogenates into SD medium. Cells with wild-type motility formed diffuse, spreading ( 1 to $3 \mathrm{~mm}$ in diameter) colonies in SD medium. Cells that were non-motile or atypically motile formed discrete pin-point $(0.2$ to $0.5 \mathrm{~mm})$ colonies.

\begin{tabular}{|c|c|c|c|c|c|c|c|c|c|}
\hline \multirow[b]{2}{*}{ Expt } & \multirow[b]{2}{*}{ Strain } & \multirow[b]{2}{*}{$\begin{array}{c}\text { No. of } \\
\text { mice }\end{array}$} & \multirow[b]{2}{*}{$\begin{array}{c}\text { Final state } \\
\text { of mice }\end{array}$} & \multirow{2}{*}{$\begin{array}{l}\text { Time after } \\
\text { inoculation } \\
\text { with } \\
\text { R. cecicola } \\
\text { (d) }\end{array}$} & \multirow{2}{*}{$\begin{array}{c}\text { No. of } \\
R \text {. cecicola } \\
\text { recovered } \\
{\left[10^{-9} \times \text { c.f.u. }\right.} \\
\left.(\mathrm{g} \text { wet } w \mathrm{t})^{-1}\right]\end{array}$} & \multicolumn{2}{|c|}{$\begin{array}{c}\text { Motile } R \text {. cecicola } \\
(\%)^{*}\end{array}$} & \multicolumn{2}{|c|}{$\begin{array}{c}\text { Proportion of mice in } \\
\text { which }<0.1 \% \text { of } \\
R \text {. cecicola were: }\end{array}$} \\
\hline & & & & & & Median & Range & Motile & $\begin{array}{l}\text { Non-motile or } \\
\text { atypically motile }\end{array}$ \\
\hline \multirow[t]{3}{*}{ A } & GM & 7 & $\begin{array}{l}\text { mono- } \\
\text { associated }\end{array}$ & $10-22$ & $5 \cdot 6$ & 37 & ND-98 & $1 / 7$ & \\
\hline & GM & 9 & $\begin{array}{l}\text { mono- } \\
\text { associated }\end{array}$ & $32-40$ & $4 \cdot 8$ & 1.6 & ND-22 & $3 / 9$ & \\
\hline & GM & 11 & $\begin{array}{l}\text { mono- } \\
\text { associated }\end{array}$ & $48-70$ & $4 \cdot 1$ & 3 & ND-18 & $4 / 11$ & \\
\hline \multirow[t]{2}{*}{ B } & GM & 9 & $\begin{array}{l}\text { penta- } \\
\text { associated }\end{array}$ & $32-40$ & 0.9 & 32 & $2 \cdot 5-85$ & & $0 / 9$ \\
\hline & GM & 9 & $\begin{array}{l}\text { penta- } \\
\text { associated }\end{array}$ & $48-70$ & 1 & 98 & $82->99.9$ & & $4 / 9$ \\
\hline C & SLS & 5 & $\begin{array}{l}\text { mono- } \\
\text { associated }\end{array}$ & $60-65$ & $3 \cdot 6$ & $<0.1$ & $\mathrm{ND}-2$ & $4 / 5$ & \\
\hline D & SLS & 5 & $\begin{array}{l}\text { penta- } \\
\text { associated }\end{array}$ & $60-65$ & $1 \cdot 2$ & 99 & $98->99.9$ & & $2 / 5$ \\
\hline
\end{tabular}

* Expressed as a percentage of the total $R$. cecicola cells recovered. 100 minus the median value would represent the percentage of recovered bacteria which were non-motile or atypically motile. ND, $R$. cecicola with wild-type motility were not detected $(<0.01 \%$ of the colonizing population).

strain GM. Some of them were subsequently associated as well with one strain each of $E$. coli, a Bacteroides sp., a Clostridium sp., and Candida pintolopesii. At various times thereafter, the animals were killed and $R$. cecicola recovered from their caeca (Table 2).

In mono-associated mice, $R$. cecicola cells with wild-type motility declined in number in the weeks following inoculation. Between 10 and $22 \mathrm{~d}$ after inoculation, $37 \%$ of the colonizing population had wild-type motility. At 32 to $70 \mathrm{~d}$ after inoculation, however, bacteria with wildtype motility were either not detectable or represented a small percentage of the total caecal population (Table 2). Although the proportion of bacteria with wild-type motility declined in mono-associated mice, such cells were not always eliminated from the caecum. Between 48 and $70 \mathrm{~d}$ after inoculation, they still represented more than $0 \cdot 1 \%$ of the caecal population in 7 of 11 animals.

In contrast to the results obtained with mono-associated mice, $R$. cecicola cells with wild-type motility predominated 38 to $60 \mathrm{~d}$ after the mono-associated mice were inoculated with four additional micro-organisms ( 48 to $70 \mathrm{~d}$ after inoculation of $R$. cecicola $\mathrm{GM}$ ) (Table 2, expt B): $98 \%$ of the recovered bacteria had wild-type motility. Indeed, the caeca of four mice yielded no non-motile cells of $R$. cecicola. That is, such cells were not recovered or were less than $0-1 \%$ of the caecal population. At earlier sampling times ( 32 to $40 \mathrm{~d}$ after $R$. cecicola inoculation), cells with wild-type motility represented a lower proportion $(32 \%)$ of the colonizing population. Thus, non-motile or atypically motile bacteria which became the majority in mono-associated caeca (Table 2, expt A), declined in numbers after the animals were colonized with additional microorganisms.

Motile bacteria not only increased as a proportion of the total colonizing population, but also increased in actual numbers, in the penta-associated animals. In the caeca of mono-associated 
mice, at 48 to $70 \mathrm{~d}$ after association, the population density of cells with wild-type motility was approximately $10^{8}$ c.f.u. $\mathrm{g}^{-1}\left(3 \%\right.$ of $\left.4 \times 10^{9}\right)$. By contrast, in penta-associated mice the population density of motile bacteria was approximately $10^{9} \mathrm{c} . \mathrm{f} . \mathrm{u} . \mathrm{g}^{-1}$. The total population levels of $R$. cecicola in penta-associated mice $\left(1 \pm 0.8 \times 10^{9}\right.$, mean $\left.\pm \mathrm{SD}\right)$ were slightly but significantly $(P<0.01$, Student $t$-test) lower than those in mono-associated mice $(4.5 \pm 2.2 \times$ $\left.10^{9}\right)$. These differences in population densities did not result from changes in caecal weights, which were the same for mono-associated and penta-associated animals.

Since motility was an important characteristic for $R$. cecicola to colonize the caecum when micro-organisms of other genera and species were present, we reasoned that non-motile mutants of the organism in mono-associated mice might evolve toward motility if such animals were further colonized by strains of other microbial species. Such a result was obtained in experiments in which mice were colonized with strain SLS $\left(\mathrm{Fla}^{-}\right)$and then with the three bacterial and one yeast strain listed above. Bacteria recovered from mice mono-associated with SLS were seldom motile (Table 2). By contrast, in penta-associated animals, most (98 to $>99.9 \%$ ) of the bacteria recovered were actively motile, resembling wild-type bacteria (Table 2). Microscopic observations of caecal homogenates of mono-associated (GM or SLS) and penta-associated mice supported the findings obtained when the bacteria were recovered in semi-solid media (Table 2). That is, $R$. cecicola cells were actively motile in homogenates of penta-associated caeca and rarely motile in homogenates of mono-associated caeca. Bacteria were present at high population densities in both caecal types.

\section{Motility of $R$. cecicola in conventional mice}

Although motile $R$. cecicola cells were favoured in penta-associated mice, non-motile cells of the organism were not excluded (Table 2). Attempts were made, therefore, to determine whether non-motile strains of $R$. cecicola could be isolated from conventional mice descended from animals from which the organism had originally been isolated (Stanton \& Savage, 1983a). Bacteria resembling $R$. cecicola were isolated from colonies in SD medium from the caeca of the descendants of such animals. Unfortunately, significant numbers of these bacteria could not be obtained because the medium, although containing nalidixic acid and tetracyline, did not sufficiently exclude growth of other caecal bacteria. Nevertheless, 29 of 76 motile strains, but 0 of 69 non-motile strains, resembled $R$. cecicola in morphology.

In other experiments, mice mono-associated with $R$. cecicola strain GM were caged with SPF mice. After the mono-associated animals acquired a complex microflora, $R$. cecicola could no longer be recovered from caecal homogenates inoculated into the selective SD medium. Thus in these animals the motility of $R$. cecicola could not be determined.

\section{DISCUSSION}

We have hypothesized that motility is a favourable adaptation for $R$. cecicola cells colonizing the mouse caecum (Stanton \& Savage, 1983a). It seemed reasonable to us, therefore, that strains that had lost wild-type motility would be unable to colonize mice. Nevertheless, as indicated by the findings reported in this paper, wild-type motility is not essential for $R$. cecicola to colonize germfree mice. Strain SLS, non-motile and non-flagellated, and strain WES, atypically motile, attained population densities equivalent to those of wild-type strain GM in mono-associated animals (Table 1). Moreover, motility mutant strains arose spontaneously from wild-type cells in mono-associated mice or were introduced with wild-type cells via the inoculum. Such non-motile and atypically motile bacteria predominated in the caeca of the mono-associated animals 32 to $70 \mathrm{~d}$ after inoculation of the animals with the wild-type strain (Table 2). Therefore not only is motility not essential for $R$. cecicola to colonize mono-associated mice, it might be regarded as a liability.

By contrast, $R$. cecicola cells with wild-type motility predominated in the caeca of mice monoassociated with either strain GM or the non-motile strain SLS and subsequently inoculated with four micro-organisms of other genera (Table 2). Thus motility is a favourable characteristic for $R$. cecicola when other micro-organisms share its environment in the gut. Motility and 
chemotaxis could enable $R$. cecicola cells to position themselves close to nutrient sources; to overcome physical barriers restrictive to other bacteria, such as the mucus layer over the intestinal epithelium; or to contact the epithelial cells, prior to establishing adherent surface populations. The results suggest that motility is important for $R$. cecicola to colonize conventional mice. Unfortunately, experimental attempts to confirm this suggestion were unsuccessful because significant numbers of $R$. cecicola could not be recovered from conventional animals.

Non-motile or atypically motile cells of $R$. cecicola may predominate in the caeca of monoassociated mice because two different types of niches are available to the colonizing bacterial cells. One type would be represented by those niches normally occupied by $R$. cecicola in conventionally colonized animals, the other by niches normally occupied by indigenous microorganisms of species other than $R$. cecicola. In support of this hypothesis is the observation that the germ-free gastrointestinal tract can be colonized to high population levels by bacterial species either unable to colonize the area in conventional mice or present in the tracts of such animals only at lower population levels (Gibbons et al., 1964; Savage, 1969; Berg, 1978). Under such circumstances, the micro-organisms in the associated ex-germfree animals must be occupying niches that they do not normally occupy in conventional animals. Cells of $R$. cecicola probably fill such empty niches in the caeca of the mono-associated mice. In filling such niches, however, without the selective pressure of other bacteria, for example in competing for similar nutrients, motility may be an unnecessary, energetically expensive trait.

Motility may be an essential characteristic for $R$. cecicola cells in mono-associated mice to colonize the caecal niches it normally colonizes in conventional mice. In those niches, $R$. cecicola strains with wild-type motility may compete successfully with non-motile strains. This hypothesis is supported by the finding that bacteria with wild-type motility could be isolated from the caeca of some mono-associated mice although they usually represent a small proportion of the total caecal population.

When other micro-organisms colonized gnotobiotic mice with $R$. cecicola, non-motile cells of $R$. cecicola were not favoured; motile cells became predominant, increasing not only as a proportion of the total $R$. cecicola population but also approximately tenfold in absolute numbers. Thus, growth of the motile bacteria may be enhanced by the other micro-organisms, either directly by favourable physiological interactions or indirectly by effects on the host or elimination of the competing non-motile $R$. cecicola cells.

The observation that colonizing bacteria such as $R$. cecicola evolve in mammalian hosts is not new. Alterations in physiological characteristics, surface properties, antigenic alterations, smooth-to-rough colony transitions, and changes in motility have been observed for microorganisms colonizing conventional as well as gnotobiotic animals (Sack \& Miller, 1969; Bloom, 1979; Gibbons \& Qureshi, 1980). A major selective force in this evolution is considered to be the immunological system of the host. The results of our experiments indicate, however, that the indigenous microflora may also influence the characteristics manifested by bacterial species colonizing a host.

T.S. was supported by a National Research Service Award from the National Institute of Allergy and Infectious Diseases (AI 06110). The research was also supported by Project Grant AI 11858 from the same Institute.

\section{REFERENCES}

ADLER, J. (1966). Chemotaxis in bacteria. Science 153 , $708-716$.

allweiss, B., Dostal, J., Carey, K. E., Edwards, T. F. \& FRETER, R. (1977). The role of chemotaxis in the ecology of bacterial pathogens of mucosal surfaces. Nature, London 266, 448-450.

ARTwohl, J. E. \& Savage, D. C. (1979). Determinants in microbial colonization of the murine gastrointestinal tract: $\mathrm{pH}$, temperature, and energy-yielding metabolism of Torulopsis pintolopesii. Applied and Encironmental Microbiology 37, 697-703.
BERG. R. D. (1978). Antagonism among the normal anaerobic bacteria of the mouse gastrointestinal tract determined by immunofluorescence. Applied and Environmental Microbiology 35, 10661073.

Bloom, B. R. (1979). Games parasites play: how parasites evade immune surveillance. Nature. London 279, 21-26.

Chet, I. \& Mitchell, R. (1976). Ecological aspects of microbial chemotactic behavior. Annual Reriew of Microbiology 30, 221- 239. 
ENomoto, M. (1965). Slow motile mutant in Salmonella typhimurium. Journal of Bacteriology 90, 1696-1702.

Freter, R., O'Brien, P. C. M. \& Halstead, S. A. (1978). Adhesion and chemotaxis as determinants of bacterial association with mucosal surfaces. In The Secretory Immune System and Caries Immunity, pp. 429-437. Edited by J. R. McGhee \& J. Mastecky. New York: Plenum Press.

Freter, R., O'Brien, P. C. M. \& Macsal, M. S. (1979). Effect of chemotaxis on the interaction of cholera vibrios with intestinal mucosa. American Journal of Clinical Nutrition 32, 128-132.

Freter, R., O'Brien, P. C. M. \& MAcsai, M. S. (1981). Role of chemotaxis in the association of motile bacteria with intestinal mucosa: in tiro studies. Infection and Immunity 34, 234-240.

Gibbons, R. J., Socransky, S. S. \& Kapsimalis, B. (1964). Establishment of human indigenous bacteria in germfree mice. Journal of Bacteriology 88, 13161323 .

GibBons, R. J. \& QuRESHI, J. V. (1980). Virulencerelated physiological changes and antigenic variation in populations of Streptococcus mutans colonizing gnotobiotic rats. Infection and Immunity 29, 10821091 .

GoRDON, J. H. \& DuBos, R. (1970). The anaerobic bacterial flora of the mouse cecum. Journal of Experimental Medicine 132, 251-260.

Guentzel, M. N. \& BerRy, L. J. (1975). Motility as a virulence factor for Vibrio cholerae. Infection and Immunity 11, 890-897.

Guentzel, M. N., Field, L. H., Eubanks, E. R. \& BERRY, L. J. (1977). Use of fluorescent antibody in studies of immunity to cholera in infant mice. Infection and Immunity 15, 539-548.

Holder, I. A., WheEler, R. \& Montie, T. C. (1982). Flagellar preparations from Pseudomonas aeruginosa: animal protection studies. Infection and Immunity 35, 276-280.

Jones, G. W., Richardson, L. A. \& UhlmaN, D. (1981). The invasion of HeLa cells by Salmonella typhimurium: reversible and irreversible bacterial attachment and the role of bacterial motility. Journal of General Microbiology 127, 351-360.

Rosebury, T. (1962). Microorganisms Indigenous to Man. New York, Toronto \& London: McGrawHill.

Sack, R. B. \& Miller, C. E. (1969). Progressive changes of vibrio serotypes in germfree mice infected with Vibrio cholerae. Journal of Bacteriology 99, 688-695.

SAVAGE, D. C. (1969). Microbial interference between indigenous yeast and lactobacilli in the rodent stomach. Journal of Bacteriology 98, 1278-1283.

SAVAGE, D. C. (1980). Colonization by and survival of pathogenic bacteria on intestinal mucosal surfaces. In Adsorption of Microorganisms to Surfaces, pp. 176206. Edited by G. Bitton \& K. C. Marshall. New York, London, Sydney \& Toronto: John Wiley.

SkeRman, V. B. D. (1969). Abstracts of Microbiological Methods. New York, London, Sydney \& Toronto: John Wiley.

Stanton, T. B. \& Savage, D. C. (1983a). Colonization of gnotobiotic mice by Roseburia cecicola, a motile, obligately anaerobic bacterium from the mouse cecum. Applied and Entironmental Microhiology 45, 1677-1684.

Stanton, T. B. \& Savage, D. C. (1983h) Roseburia cecicola, gen. nov., sp., nov., a motile, obligately anaerobic bacterium from the mouse cecum. International Journal of Systematic Bacteriology 33, 618-627.

Tannock, G. W. \& Savage, D. C. (1976). Indigenous microorganisms prevent reduction in cecal size induced by Salmonella typhimurium in vaccinated gnotobiotic mice. Infection and Immunity 13, 172179.

Whitt, D. D. \& Savage, D. C. (1980). Kinetics of changes induced by indigenous microbiota in the activity levels of alkaline phosphatase and disaccharidases in small intestinal enterocytes in mice. Infection and Immunity 29. 144-151.

YANCEY, R. J., WILlis, D. L. \& BERRY, L. J. (1978). Role of motility in experimental cholera in adult rabbits. Infection and Immunity 22, 387-392. 